\title{
Metode Monocyte Activation Test (MAT) dan Recombinant Factor C (rFC) sebagai Alternatif Metode Pengujian Pirogen bagi Perusahaan Farmasi di Indonesia
}

\author{
Andrea Santosa', Ida Bagus Made Artadana², Mariana Wahjudi² \\ ${ }^{1}$ Magister Bioteknologi, FakultasTeknobiologi, Universitas Surabaya, Surabaya, Indonesia \\ ${ }^{2}$ Fakultas Teknobiologi, Universitas Surabaya, Surabaya, Indonesia \\ Korespondensi: Mariana Wahjudi \\ Email: mariana_wahyudi@staff.ubaya.ac.id
}

Submitted : 03-09-2020, Revised : 08-12-2020, Accepted : 21-12-2020

\begin{abstract}
ABSTRAK: Peningkatan kualitas produk industri farmasi mendorong tersedianya uji yang akurat dan efisien untuk mendeteksi adanya pirogen. Endotoksin merupakan salah satu dari pirogen yang umumnya ditemukan sebagai kontaminan pada produk obat. Hingga saat ini pengujian pirogen yang digunakan secara umum di Indonesia adalah metode Rabbit Pyrogen Test (RPT) dan Limulus Amebocyte Lysate (LAL). Namun, kedua metode ini memiliki kekurangan yang hampir sama, yaitu penggunaan hewan hidup sebagai bahan uji. Untuk alasan ini, saat ini sedang dikembangkan metode in vitro yang lebih menguntungkan untuk uji pirogen, yaitu dengan Recombinant Factor C (rFC) dan Monocyte Activation Test (MAT). Tujuan dari review ini adalah memberikan pemaparan mengenai kelebihan dan kekurangan metode uji pirogen dan endotoksin yang sesuai dengan kebutuhan konsumen, serta kajian penggunaan metode alternatif pada industri farmasi di Indonesia. Diharapkan dengan pemaparan dan kajian yang diberikan dapat digunakan sebagai pertimbangan penggunaan metode uji pirogen dan endotoksin yang lebih efektif dan efisien.
\end{abstract}

Kata kunci: Pirogen; Monocyte Activation Test (MAT); Recombinant Factor C (rFC)

\begin{abstract}
The development of product quality in the pharmaceutical industry encourages the availability of accurate and efficient tests to detect pyrogens. Endotoxin is one of the pyrogens commonly found as a contaminant in medicinal products. Until recently, Rabbit Pyrogen Test (RPT) and Limulus Amebocyte Lysate (LAL) methods are frequently used to test pyrogen in Indonesia. However, these two methods have almost the same weakness, as both of the methods use animals as test material. For this reason, a more profitable in vitro method for pyrogen testing is currently being developed, namely the Recombinant Factor C ( F FC) and Monocyte Activation Test (MAT). The purpose of this review is to provide an overview of the advantages and disadvantages of pyrogen and endotoxin test methods adjust to the needs of consumers, also an explanation of the use of this alternative methods in the pharmaceutical industry in Indonesia. It is expected that this review can be used as a consideration to industry both of alternative methods as a more effective and efficient testing methods for pyrogens and endotoxin.
\end{abstract}

Keywords: Pyrogen; Monocyte Activation Test (MAT); Recombinant Factor C (rFC) 


\section{Pendahuluan}

Peningkatan industri farmasi mendorong tersedianya uji pirogen dan endotoksin yang akurat serta efisien untuk mendeteksi adanya kontaminasi. Produk-produk farmasi mungkin dapat terkontaminasi pada beberapa tahap proses produksi atau pada bahan baku yang digunakan, sehingga diperlukan adanya uji pirogen untuk mengkonfirmasi bahwa produk tidak terkontaminasi sebelum diberikan pada manusia [1]. Beberapa produk farmasi seperti infus dan obat suntik yang diberikan secara langsung ke sistem sirkulasi pembuluh darah pasien dalam jumlah besar harus steril serta terbebas dari kontaminasi endotoksin dalam batasan tertentu [2]. Berdasarkan Farmakope Indonesia Edisi VI tahun 2020 terdapat beberapa jenis obat yang diatur kandungan batas maksimum endotoksin bakteri dalam obat terutama obat untuk injeksi. Beberapa contoh obat atau injeksi tersebut adalah air steril untuk injeksi (Sterile Water for Injections) dengan batas endotoksin bakteri $\leq 0,25$ UE. $\mathrm{mL}^{-1}$ F1, amoksisilin (batas kandungan endotoksin $\leq$ 0,25 UE.mg-1 amoksisilin), injeksi ampisilin (batas kandungan endotoksin $\leq$ 0,15 UE.mg-1 ampisilin), injeksi dekstrosa (batas kandungan endotok$\sin \leq 0,5$ UE. $^{-1}$ ), dan obat injeksi yang lain [3].

Endotoksin adalah toksin yang terdapat pada bakteri gram negatif, berupa lipopolisakarida (LPS) yang terletak pada membran luar dinding sel [4]. Endotoksin dapat dilepaskan pada saat sel bakteri lisis. Oleh karena itu LPS disebut sebagai endotoksin. Sifat dari endotoksin adalah tahan panas, sehingga dapat mengkontaminasi produk farmasi yang disterilisasi. Apabila terdapat dalam jumlah besar di darah, maka endotoksin akan menimbulkan respon pirogenik yaitu peningkatan suhu tubuh, umumnya dikenal sebagai demam. Pirogen, secara umum adalah senyawa yang dapat menyebabkan kenaikan suhu tubuh [5].

Uji pirogen dimaksudkan untuk membatasi resiko reaksi demam pada tingkat yang dapat diterima oleh pasien pada pemberian sediaan in- jeksi. Pengujian pirogen meliputi kenaikan atau perubahan suhu setelah dilakukan penyuntikan sampel secara intravena pada hewan uji [3]. Saat ini, pengujian deteksi pirogen dilakukan dengan metode Rabbit Pyrogen Test (RPT). Rabbit Pyrogen Test mulai dipakai sejak tahun 1942 dan terus dipakai hingga 40 tahun kemudian. Prinsip pengujian metode RPT ini adalah pemantauan kenaikan suhu tubuh hewan uji, yaitu kelinci saat dilakukan pemberian injeksi produk sampel [6].

Pengujian endotoksin bakteri dimaksudkan untuk mendeteksi adanya endotoksin bakteri yang mungkin terdapat dalam sampel yang diuji [3]. Pengujian dilakukan menggunakan metode Limulus Amoebocyte Lysate (LAL) Test yang ditemukan sejak tahun 1980. Metode LAL test menggunakan ekstrak darah amoebosit dari kepiting tapal kuda (Lymulus polyphemus) dan dibuat khusus sebagai pereaksi LAL [7]. Pada metode ini, keberadaan endotoksin dideteksi dengan terbentuknya koagulan pada sampel positif. Dari kedua metode ini terdapat beberapa kelebihan dan kekurangan pada masing-masing metode pengujian.

Untuk memperoleh LAL, kepiting tapal kuda yang berukuran besar ditangkap, dicek kesehatannya, lalu darahnya diambil dengan menggunakan jarum suntik. Kemudian darah kepiting tapal kuda disentrifugasi untuk memisahkan amoebosit dari plasma cairnya. Amoebosit yang didapat lalu di freeze-dried dan diproses untuk digunakan. Proses untuk mendapatkan amoebosit ini memerlukan tahapan yang rumit, sehingga harga dari LAL test ini sangat mahal [8].

Semakin tingginya kebutuhan uji deteksi pirogen dan endotoksin oleh industri farmasi terkait, membuat semakin langkanya jumlah kepiting tapal kuda di dunia. Hal ini mengakibatkan harga dari kit analisa LAL yang semakin mahal. Saat ini sedang dikembangkan beberapa metode baru untuk mengatasi masalah dari metode pengujian LAL. Beberapa metode baru yang dapat digunakan sebagai pengganti LAL test antara lain ada recombinant Factor $C$ ( $\mathrm{rFC}$ ) dan Monocyte Activa- 
tion Test (MAT) [9]. Kedua metode alternatif ini memiliki beberapa kelebihan dibandingkan uji pirogen dan endotoksin dengan kelinci ataupun LAL. Adanya metode alternatif yang baru ini diharapkan dapat mengurangi penggunaan binatang dalam pengujian.

Berdasarkan Farmakope Indonesia Edisi VI tahun 2020 [3], kedua metode alternatif yang sudah ada tersebut masih belum dikenal dan diterapkan penggunaannya di industri farmasi di Indonesia. Oleh karena itu, pada review ini akan dijelaskan kelebihan dan kekurangan dari metode alternatif yang mencakup efisiensi dan efektifitas pengujian dibandingkan dengan gold standard yang sudah ada saat ini, serta kemungkinan penggunaan metode alternatif tersebut di Indonesia. Diharapkan dengan semakin berkembangnya teknologi, maka pengujian dengan menggunakan hewan sebagai alat uji dapat dikurangi bahkan dihilangkan. Selain itu, metode alternatif yang diuraikan pada review ini dapat menjadi bahan pertimbangan pengujian endotoksin di Indonesia yang lebih baik, efisien, dan efektif untuk memenuhi kebutuhan di berbagai perusahaan farmasi.

\section{Metode}

Penelitian ini merupakan kajian sistematis yang dibuat sesuai dengan pedoman Preferred Reporting Items for Systematic Review and MetaAnalyses (PRISMA). Sumber data pada penelitian ini hanya menggunakan beberapa literatur standar resmi/kompendial dan database online. Kriteria inklusi yang digunakan adalah sebagai berikut: literatur dalam Bahasa Inggris dan Bahasa Indonesia, berasal dari negara yang sedang berkembang, literatur kompendial terbitan terbaru, waktu publikasi maksimal sepuluh tahun terakhir, dan literatur penelitian fullpaper. Kriteria eksklusi yang digunakan adalah literatur dengan hasil yang tidak jelas atau membingungkan dan literatur dengan konflik kepentingan di dalamnya.

Studi yang bisa diakses secara lengkap, kemudian dipilah berdasarkan kriteria inklusi dan eksklusi yang telah ditentukan. Kemudian studi yang telah dipilih, ditelaah lebih lanjut untuk mengekstraksi data berupa nama author, tahun publikasi, metode penelitian, subjek penelitian, hasil penelitian, dan kesimpulan penelitian. Ekstraksi data dilakukan secara bertahap dengan memisahkan masing-masing data berdasarkan metode penelitian yang digunakan. Metode penelitian hasil ekstraksi data ini dibandingkan dengan gold standard dari uji pirogen dan endotoksin, yaitu metode RPT dan LAL. Jika peneliti menemukan adanya kesulitan dalam mengekstraksi data, maka peneliti meminta bantuan dari pihak kedua untuk memastikan kebenaran data yang telah diekstraksi.

\section{Hasil dan pembahasan}

Berdasarkan skema pada Gambar 1, dilakukan pencarian dengan menggunakan google scholar sebagai sumber database. Strategi pencarian dengan menggunakan kata kunci ("endotoxin test" OR "pyrogen test" OR "pyrogen" "endotoxin") AND ("Recombinant Factor C") AND ("Monocyte Activation Test") mendapatkan hasil 56 artikel. Terdapat 9 artikel diluar rentang waktu yang telah ditentukan dari kriteria, yaitu terbitan sepuluh tahun terakhir dan terdapat 1 artikel yang sama. Kemudian dari 46 artikel diseleksi lebih lanjut berdasarkan kriteria inklusi sebagai berikut, literatur menggunakan Bahasa Inggris dan Bahasa Indonesia, termasuk literatur kompendial terbaru, dan dapat diakses secara lengkap, didapatkan ada 13 artikel yang dieksklusi. Selanjutnya, 33 artikel yang tersisa diperiksa lebih lanjut berdasarkan kesesuaian judul dan abstrak artikel dengan tujuan dari review dan didapatkan ada 25 artikel yang tidak sesuai dengan tujuan. Artikel yang dieksklusikan tidak membahas mengenai metode $\mathrm{rFC}$ dan MAT sebagai metode pengujian endotoksin dan pirogen test. Berdasarkan kriteria format yang ditentukan, terdapat empat artikel yang tidak berupa format jurnal penelitian sehingga dikeluarkan. Dari hasil 


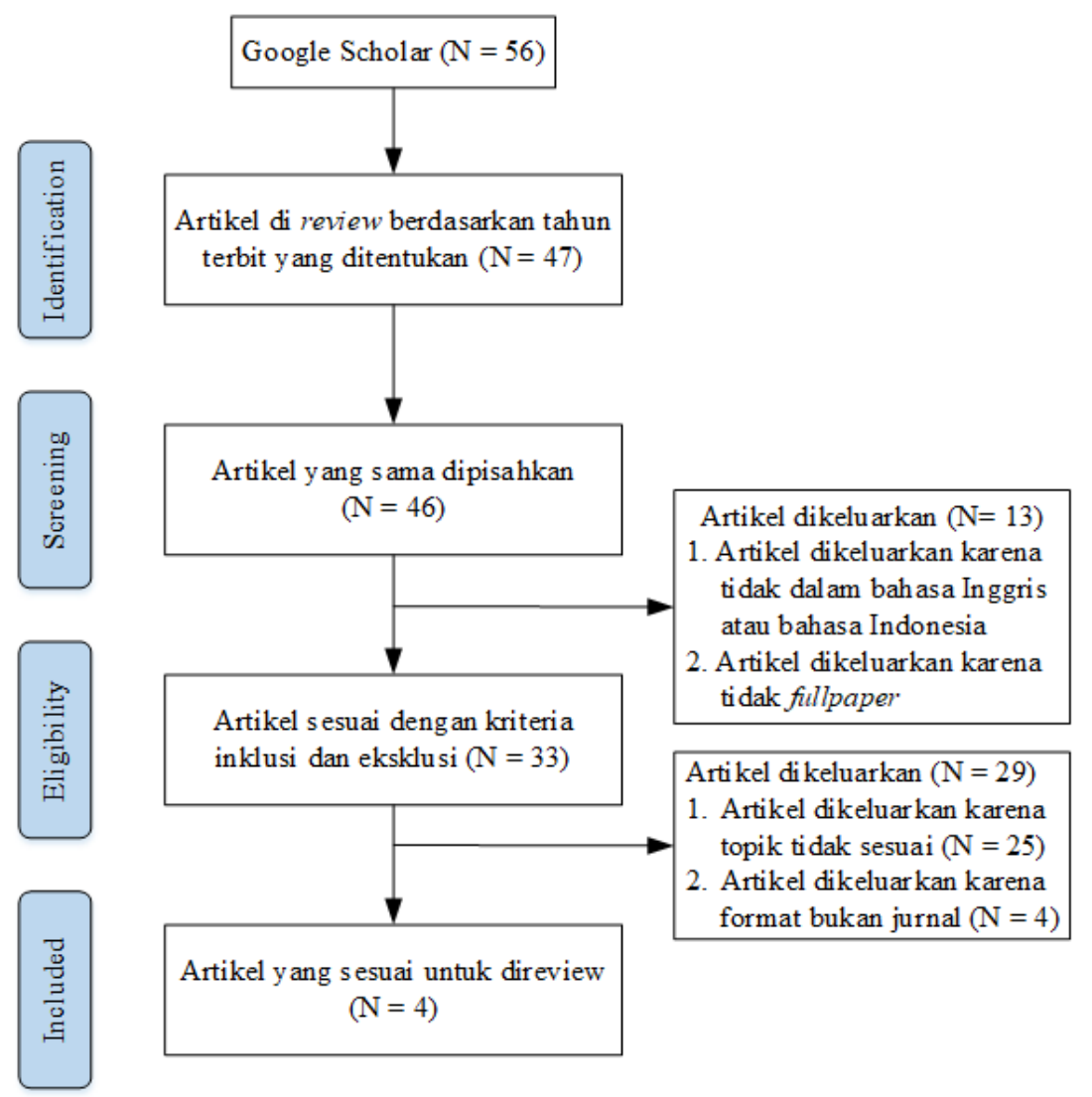

Gambar 1. PRISMA flow diagram

seleksi berdasarkan kriteria inklusi dan eksklusi yang telah ditentukan tersebut, didapatkan empat artikel untuk dikaji lebih lanjut. Keempat artikel yang dianalisa lebih lanjut, yaitu Hermanns et al. (2012), Piehler et al. (2020), Stang et al. (2014), dan Hasiwa et al. (2013) (Tabel 1).

\subsection{Hasil ekstraksi data}

Uji pirogen dan uji endotoksin sangat diperlukan dalam industri farmasi terutama untuk obat-obatan yang memerlukan proses sterilisasi. Terdapat beberapa metode pengujian endotoksin mulai dari yang konvensional hingga modern. Pengujian yang pertama kali ditemukan pada tahun 1942 adalah uji pirogenitas dengan menggunakan kelinci sebagai hewan uji atau yang dikenal dengan Rabbit Pyrogen Test (RPT) [10]. Sekelompok kelinci disuntik injeksi produk yang akan diuji dan dipantau peningkatan suhu tubuh hewan uji [8].

Setelah itu, dikembangkan uji in vitro yang memiliki tingkat sensitivitas lebih tinggi, yaitu dengan Limulus Amebocyte Lysate (LAL) yang didapat dari ekstrak sel darah kepiting tapal kuda. Uji LAL didasarkan atas kemampuan endotoksin menyebabkan koagulasi "protein coagulogen", sehingga terbentuk gel [11]. Untuk mengevaluasi hasil reaksi tersebut, ada empat metode dasar yang digunakan, antara lain: the gel-clot end point test, uji turbidimetri, uji kolorimetri, dan uji kromogenik substrat [12].

Penggunaan uji LAL semakin meningkat, sehingga dikembangkan metode baru yang merupakan alternatif dari metode LAL. Pengembangan dilakukan berdasarkan bioteknologi modern dengan menggunakan protein rekombinan. Rekombinan Faktor C $(\mathrm{rFC})$ ini merupakan versi sintetis dari protein yang diekstraksi dan dipurifikasi dari darah kepiting tapal kuda untuk mendeteksi endotoksin bakteri. Protein faktor $\mathrm{C}$ merupakan protein pertama dalam kaskade pengujian LAL [13].

Metode alternatif lain yang dapat digunakan untuk pengujian pirogen adalah metode Monocyte Activation Test (MAT). Pada MAT, dilakukan pengukuran atau deteksi secara in vitro terhadap 
Tabel 1. Hasil ekstraksi artikel

\begin{tabular}{|c|c|c|c|}
\hline $\begin{array}{l}\text { Judul penelitian, } \\
\text { penulis, tahun }\end{array}$ & Metode & Hasil & Rekomendasi \\
\hline $\begin{array}{l}\text { Alternatives to Ani- } \\
\text { mal Use for the LAL- } \\
\text { Assay } \\
\text { Hermanns et al., } \\
2012[16]\end{array}$ & $\begin{array}{l}\text { Monocyte Activa- } \\
\text { tion Test }\end{array}$ & $\begin{array}{l}\text { Penggunaan hewan pada } \\
\text { metode LAL tidak diper- } \\
\text { lukan lagi, karena dengan } \\
\text { metode MAT didapatkan } \\
\text { hasil pengujian yang lebih } \\
\text { baik dibandingkan dengan } \\
\text { LAL. }\end{array}$ & $\begin{array}{l}\text { Menggunakan MAT sebagai alternatif } \\
\text { pengganti. MAT memiliki tingkat sensi- } \\
\text { tivitas yang hampir sama dengan RPT } \\
\text { dengan variasi kemampuan deteksi } \\
\text { hingga } 6,25 \text { pg.mL } L^{-1} \text { LPS. }\end{array}$ \\
\hline $\begin{array}{l}\text { Comparison of LAL } \\
\text { and rFC Assays- } \\
\text { Participation in a } \\
\text { Proficiency Test Pro- } \\
\text { gram between } 2014 \\
\text { and } 2019 \\
\text { Piehler } \text { et al., } 2020 \\
\text { [17] }\end{array}$ & $\begin{array}{l}\text { Recombinant } \\
\text { Factor C }\end{array}$ & $\begin{array}{l}\text { Hasil dari studi ini menun- } \\
\text { jukkan bahwa metode rFC } \\
\text { dapat dibandingkan de- } \\
\text { ngan metode LAL. }\end{array}$ & $\begin{array}{l}\text { Berdasarkan tingkat keakuratan dan } \\
\text { ketepatan, uji rFC memberikan hasil } \\
\text { yang sama bahkan lebih baik diban- } \\
\text { dingkan dengan metode LAL. Metode } \\
\text { rFC dapat digunakan sebagai pengganti } \\
\text { metode LAL untuk Endotoksin Bakteri } \\
\text { Tes (BET). }\end{array}$ \\
\hline $\begin{array}{l}\text { Highly Sensitive Py- } \\
\text { rogen Detection in } \\
\text { Medical Devices by } \\
\text { the Monocyte Activa- } \\
\text { tion Test } \\
\text { Stang et al., } 2014 \\
{[18]}\end{array}$ & $\begin{array}{l}\text { Monocyte Activa- } \\
\text { tion Test }\end{array}$ & $\begin{array}{l}\text { Metode MAT dapat men- } \\
\text { deteksi jumlah pirogen } \\
\text { terkecil pada permukaan } \\
\text { peralatan medis. }\end{array}$ & $\begin{array}{l}\text { Modifikasi metode MAT dapat digu- } \\
\text { nakan untuk peralatan medis, agar } \\
\text { meningkatkan keselamatan pasien dari } \\
\text { kemungkinan kontaminasi endotoksin }\end{array}$ \\
\hline $\begin{array}{l}\text { Evidence for the } \\
\text { Detection of Non- } \\
\text { Endotoxin Pyrogens } \\
\text { by the Whole Blood } \\
\text { Monocyte Activation } \\
\text { Test } \\
\text { Hasiwa et al., } 2013 \\
\text { [19] }\end{array}$ & $\begin{array}{l}\text { Monocyte Activa- } \\
\text { tion Test }\end{array}$ & $\begin{array}{l}\text { Metode MAT dengan } \\
\text { menggunakan whole blood } \\
\text { sebagai sumber monosit } \\
\text { terbukti dapat mendeteksi } \\
\text { non-endotoksin pirogen, } \\
\text { sehingga tidak diperlukan } \\
\text { adanya validasi terkait de- } \\
\text { teksi tersebut lagi. }\end{array}$ & $\begin{array}{l}\text { Metode MAT memiliki kemampuan } \\
\text { untuk mendeteksi pirogen dari bakteri } \\
\text { gram positif. Sudah dibuktikan dan } \\
\text { divalidasi dengan berbagai penelitian } \\
\text { terkait. }\end{array}$ \\
\hline
\end{tabular}

senyawa yang mengaktifkan monosit manusia atau sel monosit yang melepaskan mediator endogen yang berperan dalam respon demam manusia yang kemudian dideteksi dengan menggunakan teknik ELISA [14]. Pada metode MAT, terdapat beberapa varian yang berbeda yang menentukan hasil pengujian, yaitu asal monosit darah manusia yang digunakan sebagai sumber dan pembacaan ELISA. Sumber monosit yang dapat digunakan antara lain whole blood cyropreserved, peripheral blood mononuclear cells (PBMC), dan MonoMac 6 (MM6) Cell Line. Perbedaan sumber monosit akan mempengaruhi sensitivitas hasil deteksi endotoksin, monosit dari sel MM 6 menghasilkan kit uji MAT yang paling baik saat ini karena memiliki sensitifitas sebesar 0,05 EU.mL ${ }^{-1}$ [15].

Pada keempat artikel yang ada memiliki kesamaan antara satu sama lain yaitu penggunaan metode alternatif, baik itu Recombinant Factor $C$ ( $\mathrm{rFC}$ ) ataupun Monocyte Activation Test (MAT) sebagai metode pengujian. Berdasarkan dari artikel yang sudah dipilih, terdapat perbedaan pada masing-masing artikel yaitu sampel pengujian yang digunakan untuk membandingkan.

Pada artikel pertama oleh Hermanns et al. (2012) [16], merupakan artikel review yang menjelaskan mengenai kemampuan metode MAT sebagai alternatif pengganti dari metode RPT dan LAL yang keduanya menggunakan hewan sebagai media uji. Metode MAT dipilih berdasarkan kriteria 3R, yaitu Replace, Reduce, and Refine, yang berarti metode MAT menggantikan LAL karena dapat mendeteksi endotoksin dan pirogen secara 
lebih baik, mengurangi penggunaan kelinci dan kepiting tapal kuda, serta menghilangkan penggunaan lisat dari darah kepiting tapal kuda. Pengembangan metode MAT yang semakin baik menunjukkan bahwa standar prosedur MAT dapat mendeteksi setidaknya 50 pg.mL $L^{-1}$ LPS pada sampel. Metode MAT merupakan metode yang memiliki reprodusibilitas dan sensitivitas yang baik, serta dapat dipertanggungjawabkan hasilnya. Kesimpulan pada artikel ini adalah metode alternatif ini dapat digunakan untuk uji pirogen menggantikan metode RPT dan LAL yang digunakan sebelumnya.

Artikel yang kedua oleh Piehler et al. (2020) [17], lebih membandingkan antara metode LAL dan metode Recombinant Factor $C$ ( $\mathrm{rFC}$ ) sebagai metode alternatif. Pengujian dilakukan dengan menggunakan 13 sampel dan membandingkan 3 kit analisa, yaitu 1 metode LAL dan 2 metode $\mathrm{rFC}$ dengan kit analisa yang berbeda. Hasilnya menunjukkan bahwa kedua kit metode rFC memberikan hasil analisa yang lebih akurat dan presisi dibandingkan metode LAL dengan tingkat ketepatan hampir 100\%. Berdasarkan perhitungan yang dilakukan antara ketiga metode tersebut, ditunjukkan bahwa metode $\mathrm{rFC}$ sangat handal, setara bahkan lebih unggul dibandingkan dengan metode LAL dan dapat digunakan untuk pengujian endotoksin bakteri.

Pada artikel ketiga oleh Stang et al. (2014) [18], pengujian pirogen dilakukan pada sampel peralatan medis dengan menggunakan metode MAT. Pengujian pirogen pada peralatan medis ini sangat diperlukan untuk menghindarkan pasien dari kontaminasi pirogen pada permukaan alat medis yang dapat mengakibatkan komplikasi pada pasien. Metode yang digunakan untuk pengujian pirogen ini adalah metode MAT dan menggunakan metode LAL sebagai pembanding. Deteksi kontaminasi endotoksin kemudian dibandingkan antara kedua metode tersebut, dan didapatkan bahwa kedua metode MAT dan LAL standar yang digunakan tidak dapat mendeteksi adanya kontaminan endotoksin. Perlu adanya modifikasi pada metode MAT agar dapat digunakan untuk mendeteksi adanya kontaminan pada permukaan peralatan medis.

Artikel terakhir dari Hasiwa et al. (2013) [19], merupakan artikel review yang menganalisa kemampuan uji dari metode MAT terhadap sampel non-endotoksin pirogenik. Data yang dikumpulkan cukup banyak mencakup hasil pengujian dengan metode MAT pada berbagai substansi media. Berdasarkan data yang ada, terbukti bahwa metode MAT dapat mendeteksi adanya non-endotoksin pirogen pada sampel yang tidak dapat terdeteksi dengan metode LAL.

Dari keempat artikel yang dikumpulkan, dapat disimpulkan bahwa metode alternatif lebih baik dibandingkan metode konvensional yang digunakan. Oleh karena itu, perlu dilakukan kajian lebih lanjut untuk penerapan kedua metode alternatif ini pada industri farmasi di Indonesia. Pemaparan mengenai kelebihan dan kekurangan masing-masing metode pengujian dapat digunakan sebagai acuan penerapan metode alternatif.

\subsection{Hasil sintesis data}

Berdasarkan Tabel 2, dapat diketahui hasil sintesis data dari keempat metode pengujian yang ada baik secara konvensional maupun metode alternatif. Pada masing-masing metode diuraikan prinsip kerja dalam menganalisa endotoksin dan pirogen. Limit deteksi atau sensitivitas dari metode pengujian dapat diketahui dan disesuaikan dengan kebutuhan dalam pengujian. Metode yang paling sensitif untuk mendeteksi endotoksin adalah metode $\mathrm{rFC}$, dengan sensitivitas hingga 0,001 EU.mL ${ }^{-1}$, sedangkan metode yang paling tidak sensitif adalah metode RPT yang dapat digantikan dengan metode MAT sebagai metode alternatif, dan diulas secara singkat kelebihan dan kekurangan dari metode uji. Kelebihan dan kekurangan dari metode uji endotoksin dan pirogen akan diuraikan lebih 
Tabel 2. Perbandingan metode pengujian RPT, LAL, rFC, dan MAT

\begin{tabular}{|c|c|c|c|c|}
\hline & $\begin{array}{l}\text { Rabbit Pyrogen } \\
\text { Test (RPT) }\end{array}$ & $\begin{array}{l}\text { Limulus Amebo- } \\
\text { cyte Lysate Test } \\
\text { (LAL) }\end{array}$ & $\begin{array}{l}\text { Recombinant Fac- } \\
\text { tor } C(\mathrm{rFC})\end{array}$ & $\begin{array}{l}\text { Monocyte Activation } \\
\text { Test (MAT) }\end{array}$ \\
\hline Prinsip analisa & $\begin{array}{l}\text { Pengukuran pe- } \\
\text { rubahan suhu tu- } \\
\text { buh setelah injeksi } \\
\text { sampel }\end{array}$ & $\begin{array}{l}\text { Penggunaan sistem } \\
\text { imun kepiting tapal } \\
\text { kuda terhadap bak- } \\
\text { teri gram negatif } \\
\text { dengan pembentu- } \\
\text { kan gel-clot }\end{array}$ & $\begin{array}{l}\text { Penggunaan hasil } \\
\text { rekombinan pro- } \\
\text { tein faktor C, yang } \\
\text { akan berpendar } \\
\text { ketika diaktifkan } \\
\text { oleh endotoksin }\end{array}$ & $\begin{array}{l}\text { Aktivasi monosit oleh } \\
\text { pirogen, menghasilk- } \\
\text { an sitokin/interleukin } \\
\text { (IL) yang terdeteksi } \\
\text { dalam uji ELISA }\end{array}$ \\
\hline Sensitivitas (EU.mL ${ }^{-1}$ ) & 0,5 & $0,01-0,03$ & $0,001-0,05$ & $0,01-0,25$ \\
\hline Kelebihan & $\begin{array}{l}\text { - Dapat mendetek- } \\
\text { si endotoksin dan } \\
\text { non-endotoksin } \\
\text { pirogen (NEP) } \\
\text { - Metode pertama } \\
\text { untuk pengujian } \\
\text { pirogen dalam } \\
\text { peraturan inter- } \\
\text { nasional dan pe- } \\
\text { doman [6] }\end{array}$ & $\begin{array}{l}\text { - Sederhana dan } \\
\text { mudah dilakukan } \\
\text { - Sensitivitas tinggi } \\
\text { - Hemat biaya [12] }\end{array}$ & $\begin{array}{l}\text { - Pengujian in vitro } \\
\text { tidak menggu- } \\
\text { nakan hewan } \\
\text { - Sederhana dan } \\
\text { mudah dilakukan } \\
\text { - Sensitivitas tinggi } \\
\text { - Hemat biaya [20] }\end{array}$ & $\begin{array}{l}\text { - Berdasarkan respon } \\
\text { demam manusia } \\
\text { terhadap pirogen } \\
\text { - Uji in vitro } \\
\text { - Dapat mendeteksi } \\
\text { endotoksin dan } \\
\text { non-endotoksin } \\
\text { pirogen (NEP) } \\
\text { - Lebih akurat, sen- } \\
\text { sitif, dan reprodu- } \\
\text { cibility baik [21] }\end{array}$ \\
\hline Kekurangan & $\begin{array}{l}\text { - Sensitivitas ren- } \\
\text { dah } \\
\text { - Uji kualitatif } \\
\text { - Tidak ada kon- } \\
\text { trol positif } \\
\text { - Uji pirogen di- } \\
\text { pengaruhi oleh } \\
\text { reaksi fisiologis } \\
\text { hewan } \\
\text { - Perlu banyak } \\
\text { hewan untuk } \\
\text { media uji } \\
\text { - Perlu biaya yang } \\
\text { besar [6] }\end{array}$ & $\begin{array}{l}\text { - Hanya dapat men- } \\
\text { deteksi endotok- } \\
\text { sin saja } \\
\text { - Dapat terganggu } \\
\text { adanya } \beta \text {-glucan } \\
\text { - Mudah terinterfe- } \\
\text { rensi oleh faktor } \\
\text { eksternal } \\
\text { - Secara tidak lang- } \\
\text { sung mengguna- } \\
\text { kan hewan se- } \\
\text { bagai bahan uji } \\
\text { [22] }\end{array}$ & $\begin{array}{l}\text { - Hanya dapat } \\
\text { mendeteksi en- } \\
\text { dotoksin } \\
\text { - Hasilnya dapat } \\
\text { terpengaruh oleh } \\
\text { faktor eksternal } \\
\text { [23] }\end{array}$ & $\begin{array}{l}\text { - Sensitivitas lebih } \\
\text { rendah dibanding- } \\
\text { kan dengan metode } \\
\text { LAL } \\
\text { - Membutuhkan } \\
\text { waktu lebih lama } \\
\text { dibandingkan de- } \\
\text { ngan LAL [24] }\end{array}$ \\
\hline
\end{tabular}

lanjut pada bagian selanjutnya.

\subsection{Kelebihan dan kekurangan RPT, LAL, rFC, dan MAT}

Pengujian dengan kelinci hingga saat ini masih sering digunakan, karena metode ini sudah lama dikenal dan digunakan untuk menguji berbagai sediaan serta terbukti memberikan hasil yang memuaskan. Selain itu, kelinci memiliki sensitivitas terhadap senyawa pirogenik yang mirip dengan manusia, sehingga kenaikan suhu dari kelinci dapat distandarisasi terhadap konsentrasi senyawa pirogen yang dapat ditoleransi manusia dan relevan [8]. Kelebihan lain dari pengujian dengan kelinci ini adalah kemampuan kelinci untuk mendeteksi semua senyawa pirogen endotoksin maupun non endotoksin [6]. Namun, terdapat pula kelemahan dari pengujian dengan menggunakan kelinci, seperti pemeliharaan dan perawatan hewan uji serta laboratorium yang lebih intensif, sensitivitas dari kelinci dipengaruhi oleh faktor eksternal lain yang dapat mengacaukan hasil, dan adanya variabilitas kelinci yang mengakibatkan respon setiap kelinci belum tentu 
sama [6].

Metode LAL sering dianggap sebagai prosedur yang paling akurat dan sensitif untuk menguji kandungan endotoksin dalam produk farmasi karena lebih kecil kemungkinan terjadi hasil false negative atau false positive. Kelebihan lain pengujian dengan LAL adalah jumlah sampel yang dibutuhkan sedikit, serta metode pengujian sudah terstandarisasi dengan sensitivitas yang dapat ditentukan, sehingga untuk biaya uji dengan metode LAL lebih murah dibandingkan dengan metode RPT. Namun kekurangan dari metode pengujian ini adalah membutuhkan waktu yang lebih panjang untuk mendapatkan hasil, karena masih belum ada sistem otomatis dengan metode ini. Selain itu, ada beberapa faktor lain yang dapat mempengaruhi hasil dari metode ini, seperti inhibitor kimia EDTA yang mengganggu reaksi LAL, denaturasi protein, gangguan $\mathrm{pH}$, dan inhibitor fisik yang dapat menyerap endotoksin [22].

Kemudian pengembangan metode baru dari LAL adalah metode Rekombinan Faktor C ( $\mathrm{rFC}$ ). Kelebihan dari pengujian dengan metode $\mathrm{rFC}$ antara lain: $r F C$ lebih spesifik terhadap endotoksin, proses produksi rekombinan protein telah divalidasi sehingga reprodusibilitas dari metode ini lebih baik dibandingkan dengan reagen LAL alami. Metode rFC merupakan metode analisa yang modern dan sederhana, cepat, spesifik, sensitif, serta lebih hemat biaya untuk endotoksin tes [20]. Perbandingan lainnya adalah metode analisa yang dilakukan, pada metode $\mathrm{rFC}$ dilakukan pengukuran berdasarkan deteksi fluoresens, sedangkan pada metode LAL pengukuran dengan deteksi absorbansi. Deteksi fluoresensi lebih sensitif dibandingkan dengan deteksi absorbansi. Ketika biosensor pada rFC yang berupa rFC zymogen diaktivasi oleh endotoksin, substrat fluorogenik akan terbelah dan menghasilkan cahaya fluoresens yang dapat terukur panjang gelombangnya. Subtrat fluorogenik diukur pada eksitasi $380 \mathrm{~nm}$ dan emisi $460 \mathrm{~nm}$, sedangkan pengujian absorbansi dengan LAL memiliki banyak kemungkinan terjadi gangguan yang mung- kin mempengaruhi hasil, seperti warna larutan, emulsi, serta suspensi. Dengan metode rFC sensitivitas deteksi endotoksin sangat tinggi, pada kisaran 0,005 EU.mL ${ }^{-1}$ hingga 0,001 EU.mL ${ }^{-1}$. Namun, kelemahan dari deteksi fluoresensi adalah semakin sensitif pengujian maka noise atau persen koefisien varian akan meningkat yang kemudian berpengaruh pada hasil replikasi [23].

Metode lain yang dikembangkan berdasarkan bioteknologi modern adalah Monocyte Activation Test (MAT). Berdasarkan European Pharmacopoeia, 2016 [25], terdapat beberapa keuntungan dari pengujian MAT dibandingkan pengujian sebelumnya yang menggunakan hewan, antara lain: sistemnya berdasarkan respons demam manusia sehingga aktivitas pirogen yang terukur lebih relevan, kemampuan untuk mendeteksi pirogen endotoksin maupun non-endotoksin [26]. Pengukuran aktivitas pirogen yang diukur berdasarkan demam pada manusia, sedangkan pada RPT aktivitas pirogen terukur berdasarkan demam pada kelinci sebagai hewan uji. Oleh karena itu, metode ini tidak menggunakan hewan sebagai alat uji pirogenitas [21]. Kelebihan lain dari metode ini adalah lebih akurat karena batas deteksi yang lebih rendah, sehingga memiliki sensivitas lebih tinggi. Biaya dan waktu pada pengujian ini lebih efisien dibandingkan dengan metode RPT [27].

Metode uji MAT saat ini sedang gencar dikembangkan karena memiliki beberapa kelebihan yang tidak ada pada uji rFC. Salah satu keunggulan dari metode MAT ini adalah kemampuan untuk mendeteksi Low Endotoxin Recovery (LER). LER merupakan fenomena ketika sampel protein mengandung buffer yang dapat mengganggu ikatan endotoksin, dapat mengakibatkan lipopolisakarida tidak terdeteksi. Pada metode LAL, LER ini merupakan kelemahan yang dapat mengakibatkan hasil false negative. Meskipun hingga saat ini belum diketahui efeknya pada manusia, namun diharapkan metode MAT dapat mengatasi gangguan LER karena metode ini meniru reaksi pirogen pada manusia [24].

\subsection{Validasi pada metode rFC dan MAT}


Kedua metode alternatif banyak diteliti orang serta dilakukan validasi serta pengujian lain untuk mengetahui spesifisitas dan sensitifitas dari masing-masing pengujian. Persyaratan minimum agar metode alternatif menjadi metode kompendial adalah metode tersebut telah divalidasi dengan tepat. Dengan hasil validasi yang baik, metode alternatif dapat setara atau lebih baik dibandingkan dengan metode kompendial. Pada metode rFC, menurut Bolden, 2019 [28], validasi yang perlu dilakukan meliputi tingkat akurasi, presisi, spesifisitas, batas kuantitasi, linearitas, jangkauan, dan ketahanan.

Berikut ini merupakan beberapa parameter validasi dari metode Recombinant Factor $C$ ( $\mathrm{rFC}$ ), yaitu:

- Spesifisitas: pada rFC tidak terdapat jalur glucan-sensitive Factor $\mathrm{G}$ yang dapat memberikan hasil positif palsu dan memberikan spesifisitas hasil yang lebih baik dibandingkan dengan metode LAL [20].

- Reprodusibilitas: protein yang digunakan pada $\mathrm{rFC}$ diproduksi secara rekombinan dan telah divalidasi, sehingga memiliki reproducibility yang lebih baik dibandingkan dengan reagen LAL yang bersumber dari alam [29].

- Sensitivitas: sensitivitas analisis dari rFC lebih baik, deteksi fluoresensi lebih sensitif dibandingkan dengan deteksi absorbansi seperti yang dilakukan pada metode LAL [20]. Hasil efektifitas dari rFC menunjukkan dapat mendeteksi kandungan endotoksin pada 100 ng protein rekombinan [30].

Telah dilakukan beberapa penelitian terkait penggunaan rFC dalam mendeteksi endotoksin, hasilnya menunjukkan bahwa metode rFC ini lebih efektif dan efisien dibandingkan dengan metode LAL yang lebih kompleks [28]. Efektifitas dari metode $\mathrm{rFC}$ telah dibandingkan dengan metode kompendial yang ada yaitu LAL, hasilnya menunjukkan bahwa metode rFC lebih efektif dan dapat menggantikan metode LAL [17].

Di sisi lain, pada metode MAT telah dilakukan pula berbagai validasi yang menunjukkan bahwa metode ini lebih baik serta efektif dan efisien dibandingkan dengan metode RPT ataupun LAL. Validasi penggunaan metode MAT dilakukan pada berbagai produk farmasi seperti serum dan vaksin [21]. Kesimpulan dari masing-masing penelitian validasi menunjukkan bahwa pengujian dengan metode MAT lebih efektif dibandingkan dengan metode RPT sebagai metode pembandingnya [31]. Selain itu, pada metode MAT tidak digunakan hewan uji sebagai media uji, sehingga hasil pengujian in vitro ini memberikan hasil yang lebih akurat dan lebih meminimalisasi adanya gangguan dari faktor eksternal. Metode MAT ini telah berhasil divalidasi dan terbukti menjadi metode yang efektif dan efisien, serta dapat diaplikasikan pada banyak bidang kesehatan, seperti obat-obatan, cairan dialisis, dan peralatan medis [32].

\subsection{Produk rFC dan MAT yang telah beredar}

Pengujian dengan metode rFC dan MAT sudah mulai digunakan oleh beberapa industri farmasi di beberapa negara [32], meskipun di Indonesia masih belum mulai digunakan. Pada Tabel 3 ditunjukkan beberapa produk yang sudah diedarkan dan dapat digunakan. Berdasar-

Tabel 3. Berbagai produk rFC dan MAT yang sudah beredar di pasaran

\begin{tabular}{|c|c|c|c|}
\hline Nama & Produsen & Tipe & $\begin{array}{l}\text { Batas deteksi } \\
\left(\mathrm{EU}_{\mathbf{m}}^{-1} \mathbf{L}^{-1}\right.\end{array}$ \\
\hline EndoZyme ${ }^{\circledR}$ II & bioMerieux SA & $\begin{array}{l}\text { Fluorescence microplate assay using Recombinant } \\
\text { Horseshoe Crab Factor C }(r F C)\end{array}$ & 0,005 \\
\hline PyroGene ${ }^{\mathrm{TM}}$ & Lonza & Recombinant Factor C Endpoint Fluorescent Assay & 0,005 \\
\hline PyroMAT $^{\circledR}$ & Sigma Aldrich & $\begin{array}{l}\text { Monocyte Activation Test (MAT) in Vitro Test Kits } \\
\text { for Pyrogen and Endotoxin Testing }\end{array}$ & 0,05 \\
\hline $\begin{array}{l}\text { MAT with the Mono } \\
\text { Mac } 6 \text { Cell Line }\end{array}$ & Confarma & MAT kits based on a cell line Mono Mac 6 & 0,05 \\
\hline
\end{tabular}


kan The 165th European Pharmacopeia (Ph. Eur.) Commission [25], mereka mengumumkan pada Desember 2019 bahwa metode rFC dapat digunakan untuk pengujian endotoksin bakteri yang akan efektif pada 1 Januari 2021. Apabila tidak ada perubahan, maka selanjutnya pengujian endotoksin dapat menggunakan metode $\mathrm{rFC}$ secara langsung tanpa perlu dilakukan validasi terlebih dahulu [34].

Dari keempat metode analisa yang sudah berkembang saat ini dapat dibedakan bahwa pemilihan metode yang akan digunakan berdasarkan keperluan dari masing-masing konsumen. Untuk pengujian pirogenitas secara keseluruhan baik karena endotoksin maupun non endotoksin dapat menggunakan Rabbit Pyrogen Test (RPT) atau Monocyte Activation Test (MAT) untuk yang lebih modern. Sementara untuk pengujian endotoksin bakterial dapat menggunakan metode konvensional dengan Limulus Amebocyte Lysate (LAL) Test atau dengan Recombinant Factor $C$ (rFC). Metode yang menggunakan aplikasi bioteknologi modern, yakni rFC dan MAT, keduanya tidak menggunakan hewan untuk proses pengujian.

Endotoksin tes dapat digunakan untuk mendeteksi adanya kontaminasi yang terjadi akibat bakteri gram negatif. Sedangkan pirogen tes untuk mendeteksi secara umum adanya respon demam yang diakibatkan oleh kontaminasi endotoksin maupun non endotoksin. Oleh karena itu, endotoksin tes umumnya dilakukan pada selama proses produksi berjalan dan digunakan pada bahan baku serta air yang digunakan saat proses produksi. Sementara itu, pirogen tes memiliki cakupan deteksi pirogen yang lebih luas termasuk endotoksin dan non endotoksin. Oleh karenanya pirogen tes dapat digunakan untuk memprediksi aktivitas pirogenik di manusia dan digunakan sebagai metode pengujian produk jadi [32].

\subsection{Aplikasi metode alternatif di Indonesia}

Berdasarkan Farmakope Indonesia Edisi VI [3], pada bagian lampiran terdapat penjelasan mengenai uji endotoksin $<201>$ dan uji pirogen $<231>$. Pada uji endotoksin bakteri, metode yang digunakan di Industri Indonesia saat ini adalah metode LAL dengan dua tipe teknik uji, yaitu teknik pembentukan jendal gel (gel-clot assay) dan teknik fotometrik. Teknik fotometrik ini mencakup metode turbidimetri,yang berdasarkan adanya kekeruhan setelah pengujian dan metode kromogenik yang berdasarkan munculnya warna. Di antara dua teknik tersebut, dapat dipilih salah satu untuk pengujian endotoksin. Apabila hasil yang didapat kurang sesuai, dapat menggunakan teknik jendal gel untuk menentukkan hasil akhir. Namun, uji pirogen yang dicantumkan pada Farmakope Indonesia masih menggunakan metode pengujian dengan pengukuran kenaikan suhu kelinci atau metode RPT [3].

Lembaga validasi metode alternatif, yaitu Interagency Coordinating Committee on the Validation of Alternative Methods (ICCVAM) [15] merekomendasikan bahwa secara umum sebuah penelitian yang optimal, dapat mencakup pengujian paralel tiga arah, dengan melakukan uji in vitro dibandingkan dengan RPT dan uji endotoksin bakteri. Ketiga uji yang dilakukan secara paralel ini untuk mengevaluasi relevansi dan kinerja dari metode in vitro yang digunakan. Oleh karena itu, metode in vitro perlu untuk diterapkan agar pengujian in vivo dapat dikurangi dengan alasan etika dan ilmiah [15]. Hingga saat ini pengujian secara in vitro belum beredar di Indonesia. Diharapkan dengan adanya pemaparan ini, industri-industri farmasi di Indonesia dapatmempertimbangkan penggunaan metode alternatif untuk tes endotoksin maupun pirogenitas. Berdasarkan data yang diakses pada https://www.merckmillipore.com/ID/ terdapat kit analisa PyroMAT ${ }^{\mathrm{TM}}$, kit ini merupakan kit untuk analisa pirogen dengan metode MAT yang menggunakan Mono-Mac 6 (MM6) cell line sebagai sumber monosit, dan menggunakan deteksi ELISA pada Interleukin-6 (IL-6). Selain itu juga terdapat Pyordetect Kit yang juga kit pengujian berbasis MAT dengan cyro-blood sebagai sumber monosit dan deteksi ELISA pada 
Interleukin-1 $\beta$ (IL-1 $\beta$ ).

Selain kit analisa dari Merck Milipore, belum ditemukan perusahaan penyedia bahan dan kit analisa yang menyediakan kit metode analisa endotoksin dan pirogen secara in vitro. Sebagian besar kit yang digunakan di industri farmasi Indonesia merupakan kit analisa LAL. Kendala yang ada pada industri farmasi di Indonesia adalah, kit analisa yang digunakan diproduksi di luar Indonesia. Oleh karena itu, perlu untuk dilakukan validasi sebelum digunakan secara masal di industri. Namun, semakin mudahnya akses dengan industri di luar negeri, diharapkan pengujian endotoksin dan pirogen di Indonesia dapat semakin maju dan berkembang.

Konsumen, terutama pelaku di bidang industri farmasi memiliki banyak pilihan pereaksi rekombinan tes untuk endotoksin bakteri pada obat-obatan atau peralatan medis. Produksi protein rekombinan secara terkontrol merupakan cara untuk tetap menjaga keberlanjutan protein yang diproduksi secara alami dari alam. Sebagian besar produk kesehatan yang telah bertransformasi menjadi obat terapeutik merupakan produk hasil produksi teknologi rekombinan [21]. Kedua metode ini baik rFC maupun MAT saat ini terus dikembangkan menjadi lebih baik sehingga diharapkan dapat membuat pengujian pirogenitas maupun endotoksin lebih efektif dan efisien di kemudian hari.

\section{Kesimpulan}

Berdasarkan kajian literatur ini dapat disimpulkan bahwa metode alternatif lebih baik dibandingkan metode konvensional. Metode pengujian yang digunakan di Indonesia saat ini adalah metode konvensional yang keduanya memiliki banyak kekurangan. Metode alternatif untuk uji pirogenitas dengan Rabbit Pyrogen Test (RPT) adalah Monocyte Activation Test (MAT), sedangkan metode alternatif untuk uji endotoksin bakteri dengan Limulus Amebocyte Lysate Test
(LAL) adalah recombinant Factor $C$ (rFC). Kedua metode alternatif ini, baik recombinant Factor $C$ (rFC) dan Monocyte Activation Test (MAT) efektif dan efisien untuk digunakan sebagai metode pengujian baik endotoksin maupun pirogen yang disarankan untuk industri farmasi di Indonesia selanjutnya. Dengan adanya pemaparan mengenai kelebihan dan kekurangan dari kedua metode alternatif ini diharapkan industri farmasi di Indonesia dapat melakukan pengujian dengan lebih efektif dan efisien.

\section{Daftar Pustaka}

1. Silveira RL, Andrade SS, Schmidt CA, Casali RG, Dalmora SL. Comparative evaluation of pyrogens tests in pharmaceutical products. Brazilian Journal of Microbiology. 2004;35(1-2):48-53.

2. Kastango ES. The ASHP Discussion Guide for Compounding Sterile Preparations. USA: American Society of Health-System Pharmacists and Baxter Healthcare Corporation; 2004.

3. Direktorat Jenderal Kefarmasian dan Alat Kesehatan. Farmakope Indonesia, Edisi VI. Jakarta : Kementerian Kesehatan RI; 2020.

4. Quinn PJ, Wang X. Endotoxins: Structure, Function and Recognition. Springer Verlag; 2010.

5. Gennaro AR, et al. Remingtons Pharmaceutical Science. 18th Edition. Pensylvania: Marck Publishing Company; 1990.

6. Park CY, Jung SH, Bak JP, Lee SS, Rhee DK. Comparison of the rabbit pyrogen test and Limulus amoebocyte lysate (LAL) assay for endotoxin in hepatitis $B$ vaccines and the effect of aluminum hydroxide. Biologicals: Journal of the International Association of Biological Standardization. 2005;33(3):145-51.

7. Iwanaga S. The limulus clotting reaction. Current opinion in immunology. 1993;5(1):74-82.

8. Fricker G. Endotoxins-Pyrogens, LAL Testing and Depyrogenation, Kevin L. Williams (Ed.), New York, Oxon: Informa Healthcare; 2007. 
9. Tamura H. The Road to Next Generation LAL Technology. EC Bacteriology and Virology Research ECO. 2016;01:04-05.

10. Bang FB. A bacterial disease of Limulus polyphemus. Bull Johns Hopkins Hosp. 1956;98(5):325-51.

11. Levin J, Bang FB. Clottable Protein in Limulus: Its Localization and Kinetics of Its Coagulation by Endotoxin. Thrombosis et diathesis haemorrhagica. 1968;19.186-97.10.1055/s0038-1651195.

12. Mehmood Y. What Is Limulus Amebocyte Lysate (LAL) and Its Applicability in Endotoxin Quantification of Pharma Products. In Growing and Handling of Bacterial Cultures 2019 Jan 8. IntechOpen.

13. Loverock B, et al. Stimuli to the Revision Process: A Recombinant Factor $C$ Procedure for the Detection of Gram-negative Bacterial Endotoxin. USP Pharmacopoeial Forum 36(1). 2010.

14. Poole S, Gaines Das RE. Towards a 'Human Pyrogen Test'. Eur. J. Parenter. Sci., 2001;6:63-4.

15. Interagency Coordinating Committee on the Validation of Alternative Methods (ICCVAM), ICCVAM Test Method Evaluation Report: Validation Status of Five in vitro Test Methods Proposed for Assessing Potential Pyrogenicity of Pharmaceuticals and Other Products (NIH Publication, n. 08e6392). 2008.

16. Hermanns J, Bache C, Becker B, Loeschner B, Montag T, Spreitzer I. Alternatives to animal use for the LAL-assay. ALTEX Proceedings. 2012;1(12):81-4.

17. Piehler M, Roeder R, Blessing S, Reich J. Comparison of LAL and rFCAssays-Participation in a Proficiency Test Program between 2014 and 2019. Microorganisms. 2020;8(3):418.

18. Stang K, Fennrich S, Krajewski S, Stoppelkamp S, Burgener IA, Wendel HP, Post M. Highly sensitive pyrogen detection on medical devices by the monocyte activation test. Journal of Materials Science: Materials in Medicine. 2014;25(4):1065-
75.

19. Hasiwa N, Daneshian M, Bruegger P, Fennrich S, Hochadel A, Hoffmann S, Rivera-Mariani FE, Rockel C, Schindler S, Spreitzer I, Stoppelkamp S. Evidence for the detection of non-endotoxin pyrogens by the whole blood monocyte activation test. Alternatives to animal experimentation: ALTEX. 2013;30(2):169-208.

20. Bolden J, Smith K. Application of Recombinant Factor C Reagent for the Detection of Bacterial Endotoxins in Pharmaceutical Products. PDA J Pharm Sci Technol. 2017;71(5):405-12.

21. da Silva CC, Presgrave OA, Hartung T, de Moraes AM, Delgado IF. Applicability of the Monocyte Activation Test (MAT) for hyperimmune sera in the routine of the quality control laboratory: Comparison with the Rabbit Pyrogen Test (RPT). Toxicology in vitro. 2016;32:70-5.

22. Chen L, Mozier N. Comparison of Limulus amebocyte lysate test methods for endotoxin measurement in protein solutions. Journal of pharmaceutical and biomedical analysis. 2013;80:180-5.

23. Ding JL, Ho B. Endotoxin Detection-from Limulus Amebocyte Lysate to Recombinant Factor C. In: Wang X, Quinn PJ, editors. Endotoxins Struct. Funct. Volume 53. Springer Netherlands; Dordrecht, The Netherlands. pp. 2010;187-208.

24. Reich J, Weyer FA, Tamura H, Nagaoka I, Motschmann H. Low endotoxin recoveryMasking of naturally occurring endotoxin. International journal of molecular sciences. 2019;20(4):838.

25. European Pharmacopoeia Commission adopts revised general chapter on Monocyte Activation Test to facilitate reduction in testing on laboratory animals. EDQM, 2016.

26. Hartung T. The human whole blood pyrogen test: lessons learned in twenty years. ALTEX: Alternatives to Animal Experimentation. 2015;32(2):79-100.

27. Potu A, Burra S, Patil AK. Monocyte Activation Test: A New Pharmacoepial Quality Control Test 
For Pyrogens-A Review. Journal of Advanced Pharmaceutical Sciences. 2011;1(1):122-31.

28. Bolden J. Recombinant Factor C 2019;10,1007/978-3-030-17148-3_13.

29. Abate W, Sattar AA, Liu J, Conway ME, Jackson SK. Evaluation of recombinant factor $\mathrm{C}$ assay for the detection of divergent lipopolysaccharide structural species and comparison with Limulus amebocyte lysate-based assays and a human monocyte activity assay. Journal of Medical Microbiology. 2017;66(7):888-97.

30. Schwarz H, Schmittner M, Duschl A, HorejsJoeck J. Residual endotoxin contaminations in recombinant proteins are sufficient to activate human CD1c+ dendritic cells. PLoS One. 2014;9(12):e113840.

31. Perdomo-Morales R, Pardo-Ruiz Z, Spreitzer I, Lagarto A, Montag T. Monocyte activation test (MAT) reliably detects pyrogens in parenteral formulations of human serum albumin.
ALTEX-Alternatives to animal experimentation. 2011;28(3):227-35.

32. Schindler S, Von Aulock S, Daneshian M, Hartung T. Development, validation and applications of the monocyte activation test for pyrogens based on human whole blood. ALTEX-Alternatives to animal experimentation. 2009;26(4):265-77.

33. Krisfalusi-Gannon J, Ali W, Dellinger K, Robertson L, Brady TE, Goddard MK, Tinker-Kulberg R, Kepley CL, Dellinger AL. The role of horseshoe crabs in the biomedical industry and recent trends impacting species sustainability. Frontiers in Marine Science. 2018;5:185.

34. Guidance for Industry Pyrogen and Endotoxins Testing: Questions and Answers, U.S. Food and Drug Administration, June 2012.

35. Millipore. Preparation, Separation, Filtration \& Testing Products PyroMAT. 2018. [Diakses pada 16 September 2020], diakses dari https://www. merckmillipore.com/ID/ 